\title{
Effects of Arctic Warming on Microbes and Methane in Different Land Types in Svalbard
}

\author{
Fang Zhang ${ }^{1,+} \mathbb{D}$, Han Zhang ${ }^{1,+}$, Shaofeng Pei ${ }^{2,3, *}$, Liyang Zhan ${ }^{4} \mathbb{D}$ and Wangwang Ye $^{4}(\mathbb{D}$ \\ 1 MNR Key Laboratory for Polar Science, Polar Research Institute of China, Shanghai 200136, China; \\ zhangfang@pric.org.cn (F.Z.); zhanghan@pric.org.cn (H.Z.) \\ 2 Laboratory for Marine Geology, Qingdao National Laboratory for Marine Science and Technology, \\ Qingdao 266071, China \\ 3 Laboratory of Ecological Geology and Climate Change, Qingdao Institute of Marine Geology, \\ Qingdao 266237, China \\ 4 MNR Key Laboratory of Global Change and Marine-Atmospheric Chemistry, Third Institute of \\ Oceanography, Xiamen 361000, China; zhanliyang@tio.org.cn (L.Z.); yewangwang@tio.org.cn (W.Y.) \\ * Correspondence: peishaofeng@gmail.com; Tel.: +86-186-6192-1532; Fax: +86-0532-85720553 \\ + Co-fist authors: F.Z. \& H.Z.
}

check for updates

Citation: Zhang, F.; Zhang, H.;

Pei, S.; Zhan, L.; Ye, W. Effects of Arctic Warming on Microbes and Methane in Different Land Types in Svalbard. Water 2021, 13, 3296. https://doi.org/10.3390/w13223296

Academic Editor:

Alexander Shiklomanov

Received: 6 August 2021

Accepted: 2 November 2021

Published: 21 November 2021

Publisher's Note: MDPI stays neutral with regard to jurisdictional claims in published maps and institutional affiliations.

Copyright: (c) 2021 by the authors. Licensee MDPI, Basel, Switzerland. This article is an open access article distributed under the terms and conditions of the Creative Commons Attribution (CC BY) license (https:// creativecommons.org/licenses/by/ $4.0 /)$.
Abstract: Climate change is having a profound impact on Arctic microbiomes and their living environments. However, we have only incomplete knowledge about the seasonal and inter-annual variations observed among these microbes and about their methane regulation mechanisms with respect to glaciers, glacial melting, snow lakes and coastal marine water. This gap in our knowledge limits our understanding of the linkages between climate and environmental change. In the Arctic, there are large reservoirs of methane which are sensitive to temperature changes. If global warming intensifies, larger quantities of methane stored in deep soil and sediments will be released into the atmosphere, causing irreversible effects on the global ecosystem. Methane production is mainly mediated by microorganisms. Although we have some knowledge of microbial community structure, we know less about the methane-correlated microbes in different land types in the Svalbard archipelago, and we do not have a comprehensive grasp of the relationship between them. That is the main reason we have written this paper, in which current knowledge of microorganisms and methane-correlated types in High Arctic Svalbard is described. The problems that need to be addressed in the future are also identified.

Keywords: climate change; High Arctic Svalbard; different landforms; microbial community; methane production and consumption; distribution and correlation

\section{General Description of Microorganisms}

Microorganisms (i.e., organisms $<200 \mu \mathrm{m}$, mainly prokaryotes, archaea, microalgae, fungi, protozoa, etc.) are ubiquitous in the ecosystem, playing multiples roles as producers, consumers and decomposers. They are not only the providers of food sources for medium and large animals, but also responsible for many important processes, such as nutrient mineralization. They are the basis of ecosystems and are the main components of the marine microbial food loop (Figure 1). Autotrophic microorganisms-chiefly phytoplankton and some photosynthetic bacteria, such as cyanobacteria-absorb carbon dioxide $\left(\mathrm{CO}_{2}\right)$. Microorganisms adapted to cold conditions are called psycrophiles. Most microorganisms in the high Arctic are psychrophiles. Examples include ice algae and phytoplankton, such as some Phaeocystis, which produce dimethylsulfoniopropionate (DMSP) and thereby have a negative effect on global warming [1-3]. By contrast, some species of archaea, bacteria, microalgae and protozoa can produce methane $\left(\mathrm{CH}_{4}\right)[4-8]$ and greenhouse gases, such as $\mathrm{CO}_{2}$ (through biological respiration), which contributes to global warming. So even though these organisms are small, their functions are not insignificant. However, as more than $99 \%$ of these organisms are unculturable, our knowledge of them is inadequate [9]. 


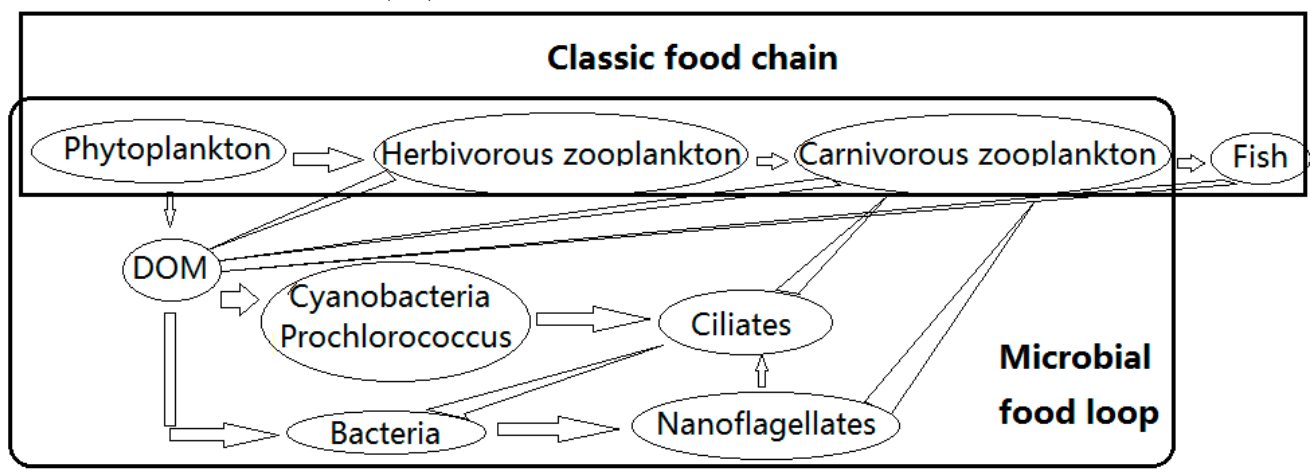

Figure 1. Microbial food loop and classic food chain.

Baas Becking and Beijerinck said of these microorganisms that they are "Everything in Everywhere, but, the environment selects $[10,11]$ ". Microorganisms are sensitive to environmental changes and can reflect these changes in variations in community composition, biomass and functions [5]. They are present in the soils of the Arctic, in the atmosphere, seawater and sediments, freshwater lakes and sediments, glaciers and melting streams, sea ice and surface melting pools and subsea ice seawater. However, the structures and functions of microbial communities are different in different mediums $[3,4,12,13]$.

\section{General Information about High Arctic Svalbard}

The Yellow River Station is located in High Arctic Ny-Ålesund (Figure 2), Svalbard $\left(74^{\circ} \sim 81^{\circ} \mathrm{N}, 10^{\circ} \sim 35^{\circ} \mathrm{E}\right)$. Svalbard has more than 2100 glaciers covering nearly $60 \%$ of its land surface. The archipelago is one of the most significant warming areas in the Arctic: local observations show that the average annual temperature in 2006 was $-6.7^{\circ} \mathrm{C}$. Comparatively, it jumped to $-1.8^{\circ} \mathrm{C}$ ten years later. The average annual temperature has increased by nearly $5^{\circ} \mathrm{C}$ in 14 years. The ice-free period increased by 3.3 days per year and the surface temperature increased by $0.5^{\circ} \mathrm{C}$ during 1980-2010. In western Svalbard, there was a high temperature of $4.9^{\circ} \mathrm{C}$ and rainfall higher than $65 \mathrm{~mm}$ recorded in January 2018 in Ny-Ålesund. This is very unusual. Continued warming has led to rapid glacial melting and glacial retreat, with an area reduction of about $512 \mathrm{~km}^{2}$ between 1961 and 1993. An inflow glacier in Ny-Ålesund named Kongsbreen Glacier has retreated by $5 \mathrm{~km}$ or $166 \mathrm{~m}$ per year in the past 30 years (Figure 3; [14]). Melting glaciers lead to large amounts of fresh water flowing into the Kongsfjorden, an Atlantic coastal water. The fresh water flow into Kongsfjorden is estimated to be as high as $130 \mathrm{~m}^{3} / \mathrm{s}$ in melting seasons, and the annual inflow is $1.4 \mathrm{~km}^{3}$ [15]. In addition, the land glacier front has also retreated with an increasing surface runoff. This has carried large amounts of terrigenous materials into the sea, which has exerted great and far-reaching effects on the coastal marine ecosystem. Glacial melting, seawater temperatures rising and the permafrost thawing may exacerbate greenhouse gas emissions, resulting in changes to the environment and the community structures and functions of microbes living there [16]. 


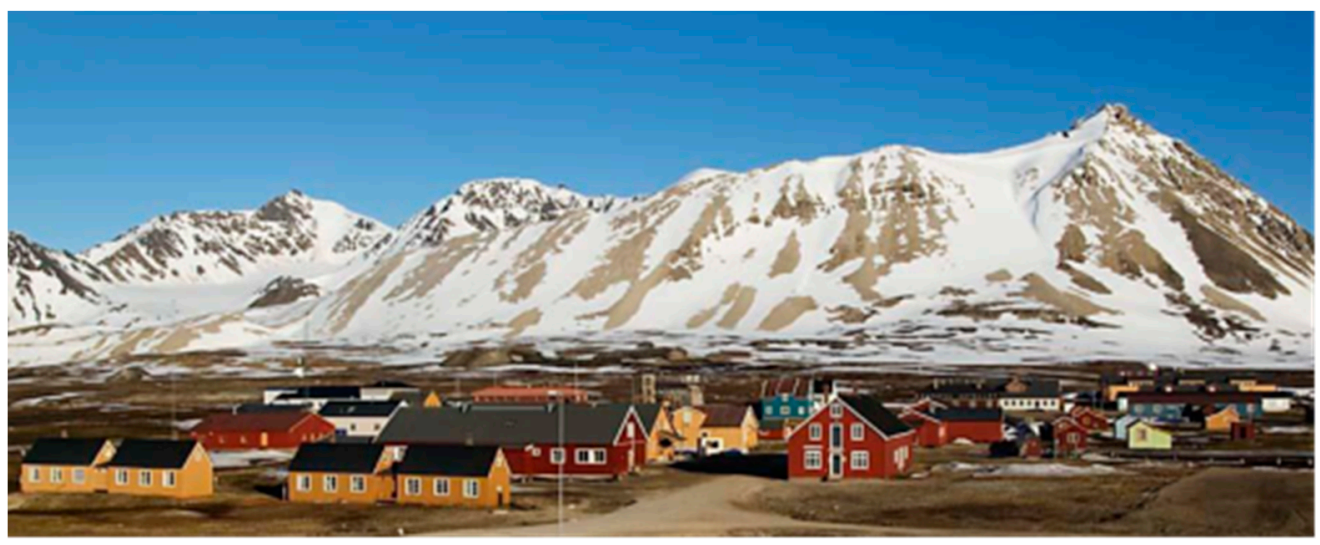

Figure 2. The world's northernmost scientific research town. Airscape at Ny-Ålesund (from Kings Bay AS).
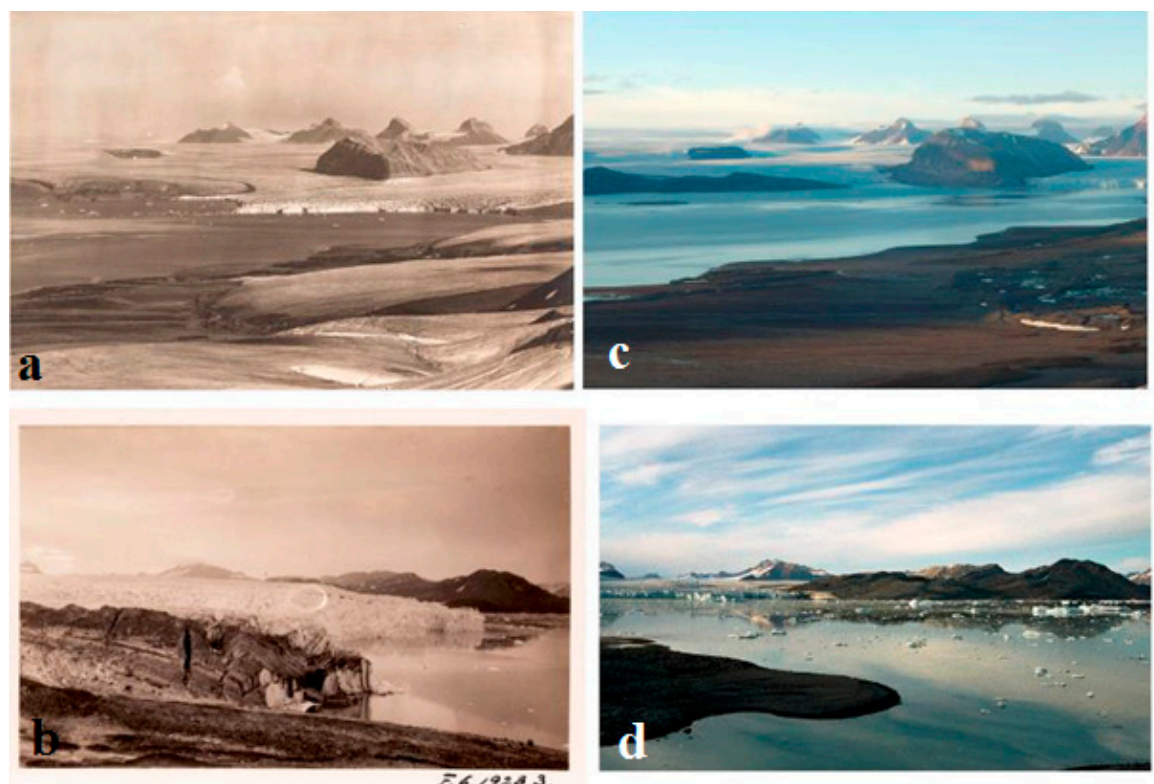

Figure 3. The glacier front in Svalbard has retreated significantly in the past 80 years. $(\mathbf{a}, \mathbf{b})$ Glacier front 80 years ago (c,d). The present glacier front. Source: (https://image.so.com/i?src=360pic strong\& $z=1 \& \mathrm{i}=0 \& \mathrm{cmg}=154 ; 25$ February 2018).

\section{General Study of Microbes and the Environment in Kongsfjorden, Ny-Ålesund}

The Arctic Kongsfjorden $\left(79^{\circ} \mathrm{N}, 12^{\circ} \mathrm{E}\right.$ ) (Figure 4), the most studied fjord in the region, is an inner bay on the northwest coast of Svalbard. Kongsfjorden is influenced by both the North Atlantic Current and glacial melt water (Figure 5; [17]). The warm Atlantic current has increased significantly in recent years [17]; its presence is detected even in winter [18]. It has been non-icebound in winter in the past decade [19]. In addition, stratification and salinity at the bottom of Kongsfjorden is increasing, which has a great impact on the biota there [20-22]. The sensitivity of Kongsfjorden to climatic changes makes it an ideal place to study climatic effects on Arctic coastal ecosystems [20,23-25]. 

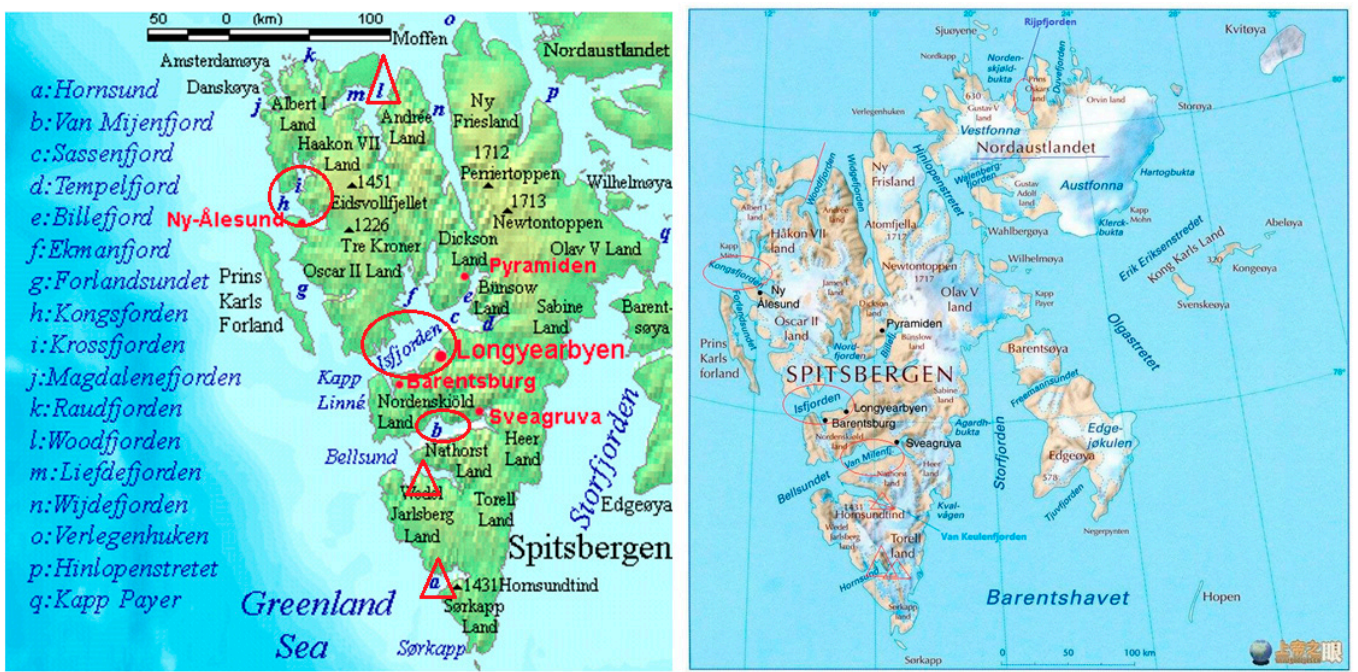

Figure 4. Distribution of various fjords on Svalbard.

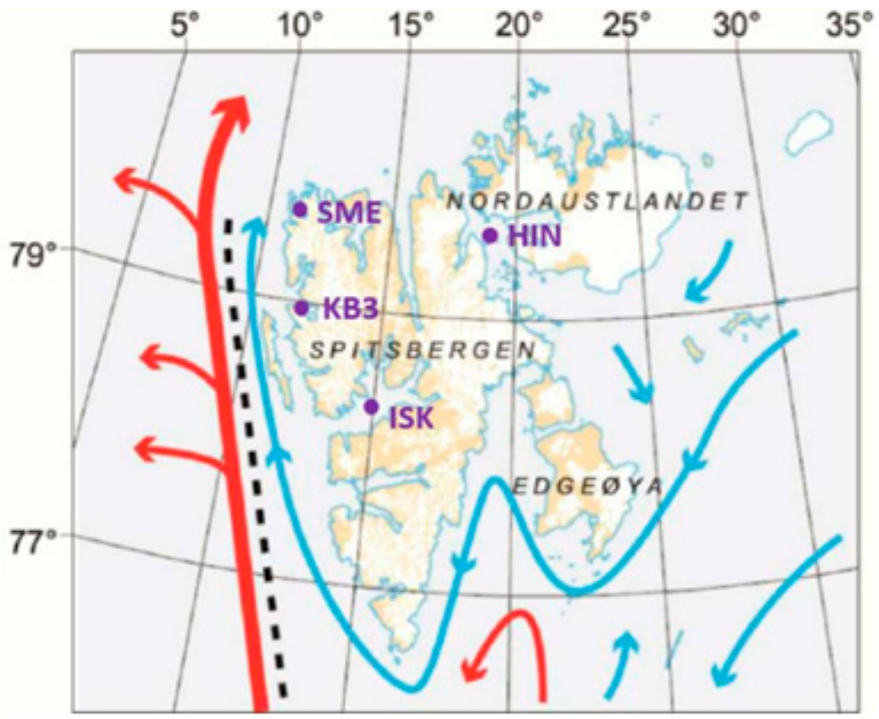

Figure 5. Map of the Svalbard archipelago, showing Atlantic water in the West Spitsbergen Current (red arrows), and Arctic water forming an Arctic coastal current (blue arrows). Dotted line indicates mixing between the two currents. ISK = Isfjorden; KB3 = Kongsfrorden; SME = Smeerenburgfroden; $\mathrm{HIN}=$ Hinlopen [15].

Microplankton are the basis of the food web in Kongsfjorden. There are obvious seasonal variations: diatom or haptophyte (Phaeocystis) blooms usually occur in spring (April to May) [26], and chlorophytes and cryptophytes may become dominant populations later in the year [27]. The dominant species in the community fluctuated greatly in summer: diatoms, chlorophyta, dinoflagellates, cryptoflagellates and ciliates could each be the dominant species [28-30]. Prokaryotes in both water and sediments in summer were mainly represented by Proteobacteria, Bacteroidetes, Verrucomicrobia and Actinobacteria $[13,31]$. Chlorophyta, Prymnesiophyta (Phaeocystis) and heterotrophic dinoflagellates may become dominant species in the early autumn community [27]. Increases in both glacial melting and land surface runoff affect the timing and community structure of spring algal blooms [27]. Large amounts of glacial melting leads to lower primary and secondary productivities [21] and also changes the community structure in the peak melting period [27,32], as glacial melt water brings quantities of glacial and terrestrial organic and inorganic substances into Kongsfjorden. This leads to a significant decrease of water 
temperature, salt, transmittance and thinning of the euphotic layer and an increase of stratification which reduces nutrient inputs. All these lead to negative effects on individual plankton and the original plankton community structures in the fjord [12,13]. We observed a large number of freshwater Chrysophyta (Poterioochromonas malhamensis) in Kongsfjorden in the summer of 2013 (Figure 6; [33]). In addition, the increase of warm Atlantic water also changes the planktonic ecosystem. For example, we observed a large number of warm water dinoflagellates in the summer of 2015. In addition, Caroppo et al. (Figure 7) observed a rare harmful dinoflagellate bloom in the late summer [34]. Little difference was observed in the distribution of dinoflagellates between the inner and outer reaches of Kongsfjorden. This is significantly different from the microalgal dominant community and the relationship between the community and environmental factors in the year of 2012 (Figure 8; [12,31]).
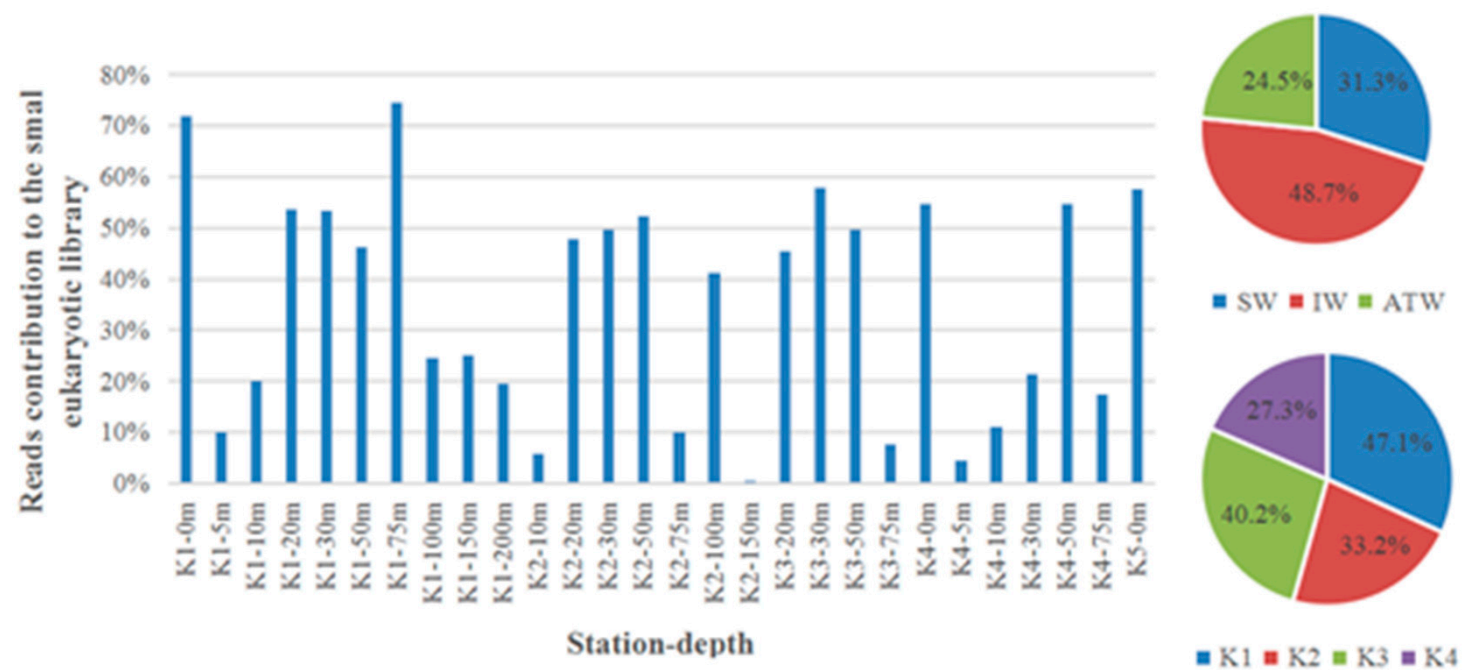

$\mathrm{m} 1 \mathrm{~K} 2 \mathrm{~K} 2 \mathrm{~K} 3 \mathrm{~m} 4$

Figure 6. Contributions of Poterioochromonas malhamensis to microeukaryotic DNA library from different water masses and water-layers at different stations in the Kongsfjorden. SW = surface water; IW = intermediate mixed water; TAW $=$ Transformed Atlantic water [31].
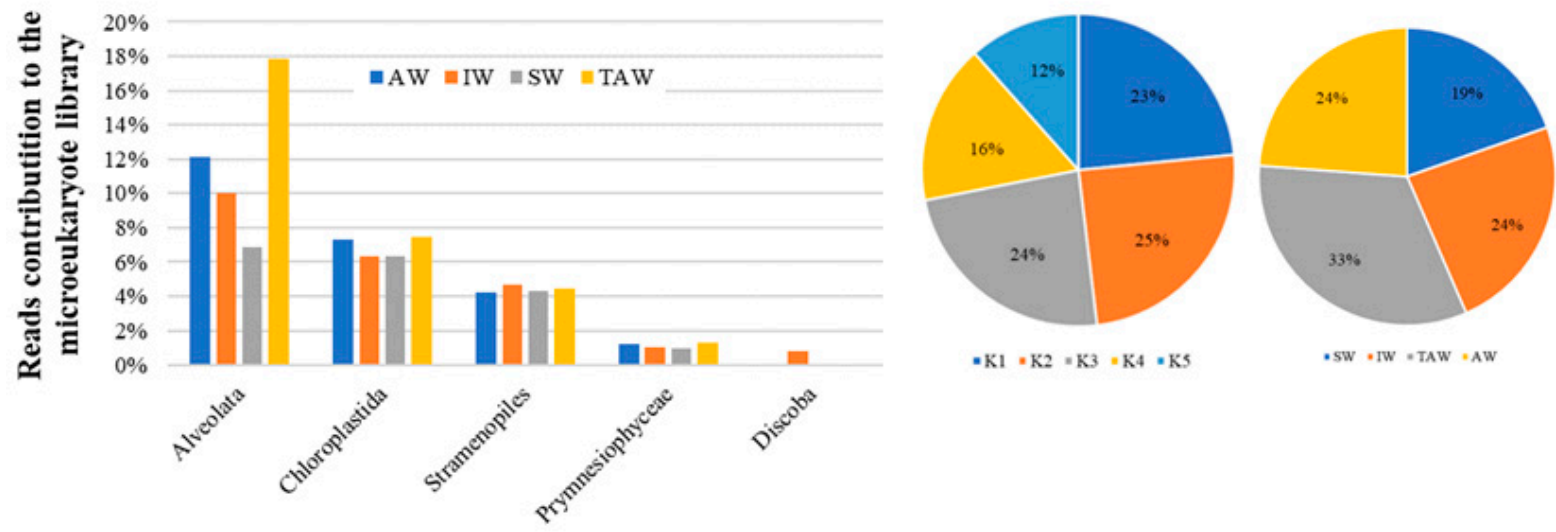

\section{Microeukaryote classes}

Figure 7. Proportion of microeukaryotic plankton in Kongsfjorden in 2015. Only classes with proportional contributions of no less than $1 \%$ to the DNA library were shown. SW = surface water; IW = intermediate mixed water; TAW = Transformed Atlantic Water. 


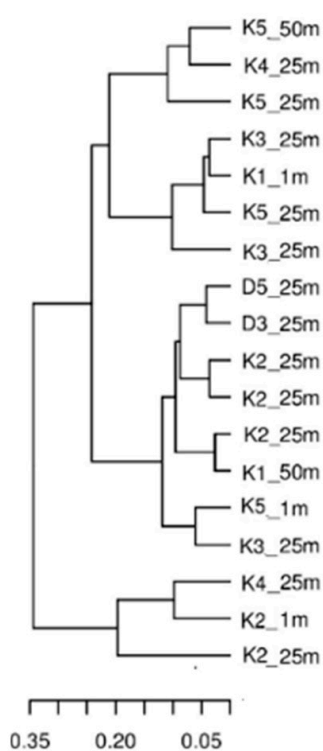

dist method=bray clust method=complete
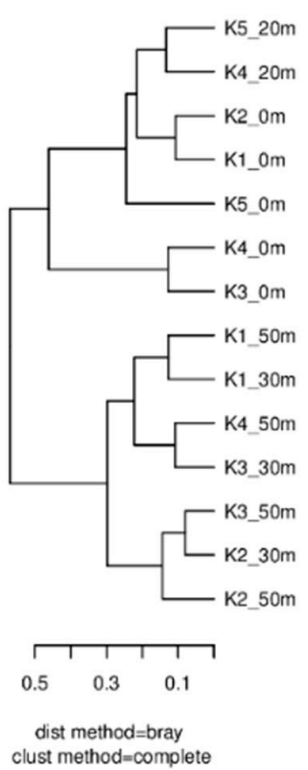
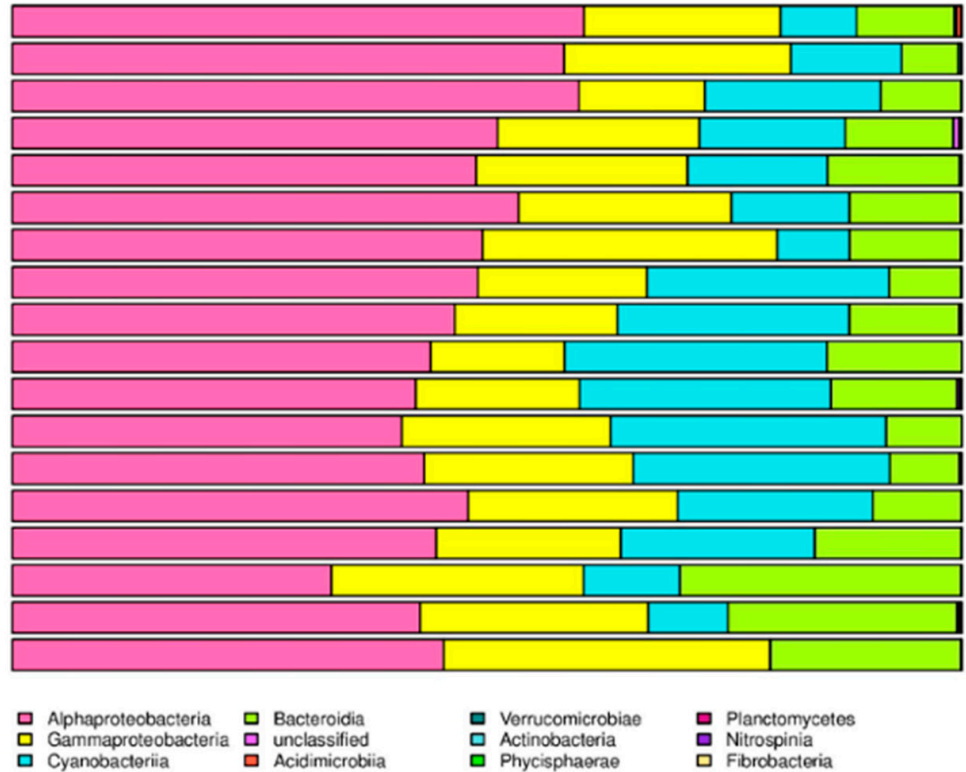

ㅁ. Verrucomicrobiae - Phycisphaerae

ㅁ Planctomycetes F Fibrobacteria

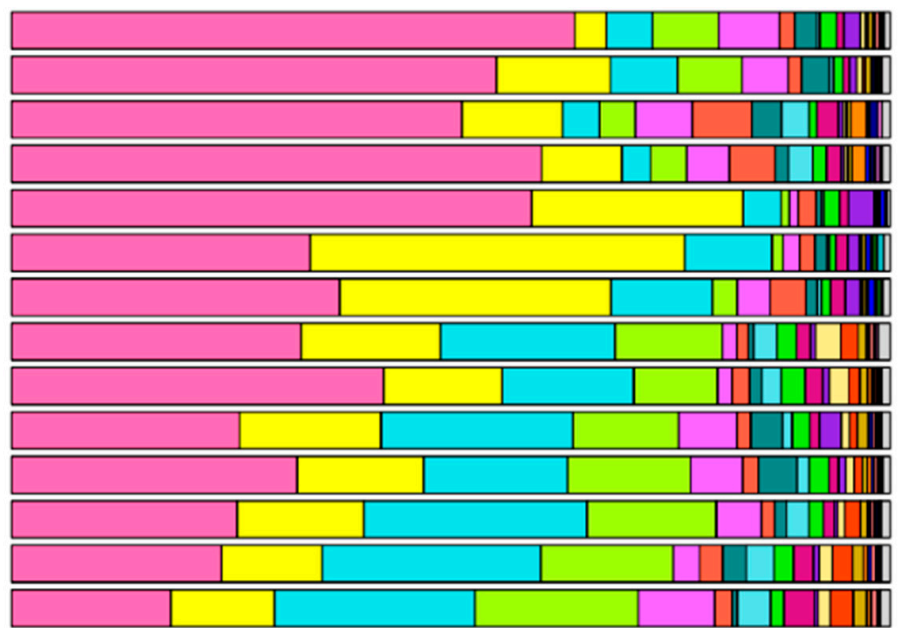

S Spirotrichea

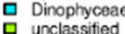

Chrysophyco

Thecofilosea

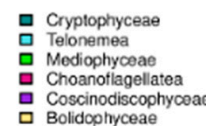

ㅁ Picomonadea

$\begin{array}{lll}\text { Picomonadea Litostomatea } & \\ \text { Dictyochophyceae } & \text { 口 Pelagophyce }\end{array}$

Chlorarachniales

Pyramimonadophyceae o Others $(<0.5 \%)$

Labyrinthulomycotes
Chlorarachniophyceae

b

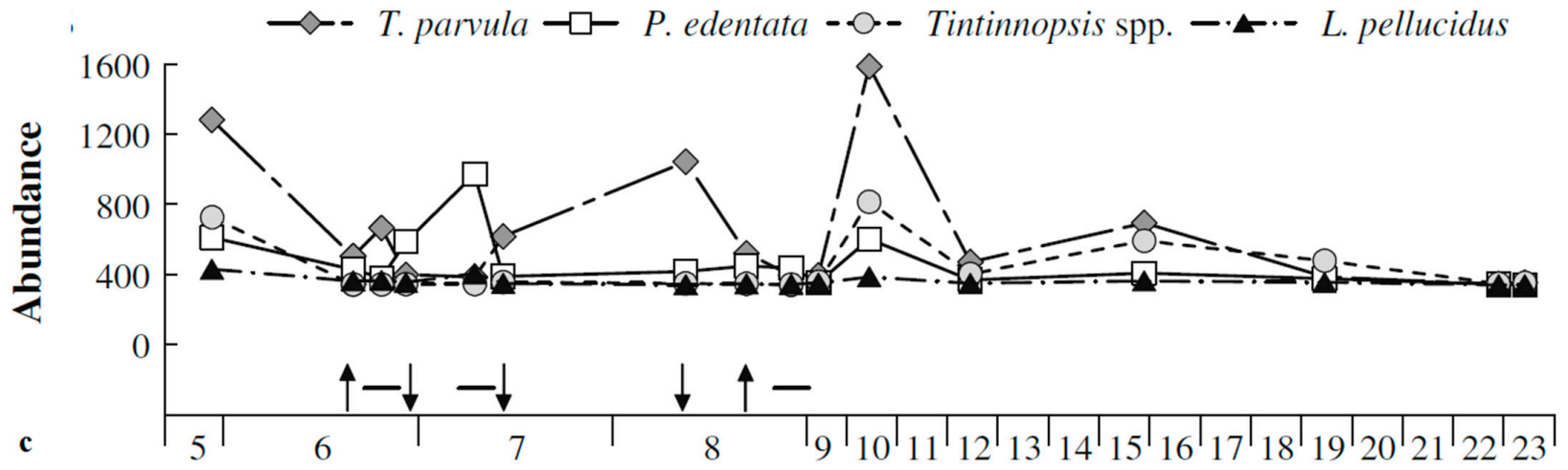

Figure 8. Distribution map of main microplankton communities in Kongsfjorden in 2012: (a) Prokaryotes, (b) Eukaryotes and (c) Ciliates. The arrows in Figure $8 \mathrm{c}$ indicate the dates on which the abundance data were collected [12,35]. 
As shown in Figure 8, the structure of the prokaryote community in 2012 [13] was mainly composed of $\beta$ - and $\gamma$-Proteobacteria, Actinobacteria and Bacteroidetes, while the eukaryotes were mainly composed of Mamiellophyceae, Spirotrichea and Telonemea [12]. The main ciliates were of the genus Tintinnopsis, mainly Tintinnopsis parvula, Parafavella edentata, Tintinnopsis spp and Leprotintinnus pellucidus [35]. However, the prokaryotes were almost all $\alpha$-proteobacteria and the main genus of ciliates, Tintinnopsis, was not found when P. malhamensis was dominant in 2013 (Figure 6). One can see, then, the competitive or interdependent relationships among microorganisms [31].

Zooplankton biomass in Kongsfjorden has increased significantly in the past decade [23] and contains many Atlantic as well as more widespread species [32,36]. In addition, our own study also showed that in 2018 (Figure 9), the biomass of micro-protozoa can account for more than $93 \%$ of the total biomass, and that their distribution was closely related to the location of its food, i.e., prokaryotes and phytoplankton. Archaebacteria increased greatly. This type of prokaryotes was mainly distributed in the warm currents of the Atlantic Ocean, while the proportion of dinoflagellates in warm water also greatly increased [25].
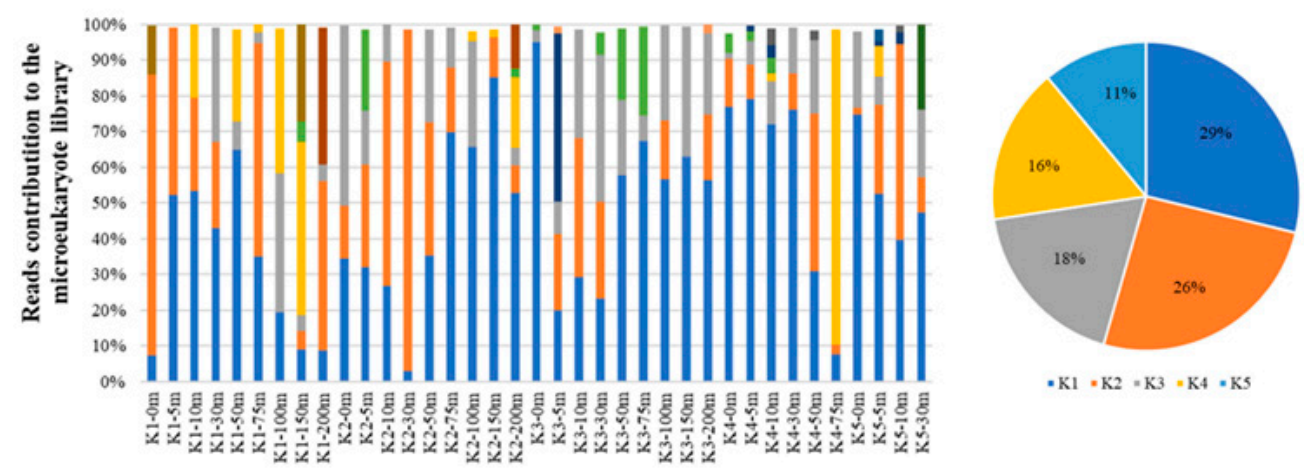

$\cdot \mathrm{K} 1 \cdot \mathrm{K} 2 \cdot \mathrm{K} 3=\mathrm{K} 4 \cdot \mathrm{K} 5$
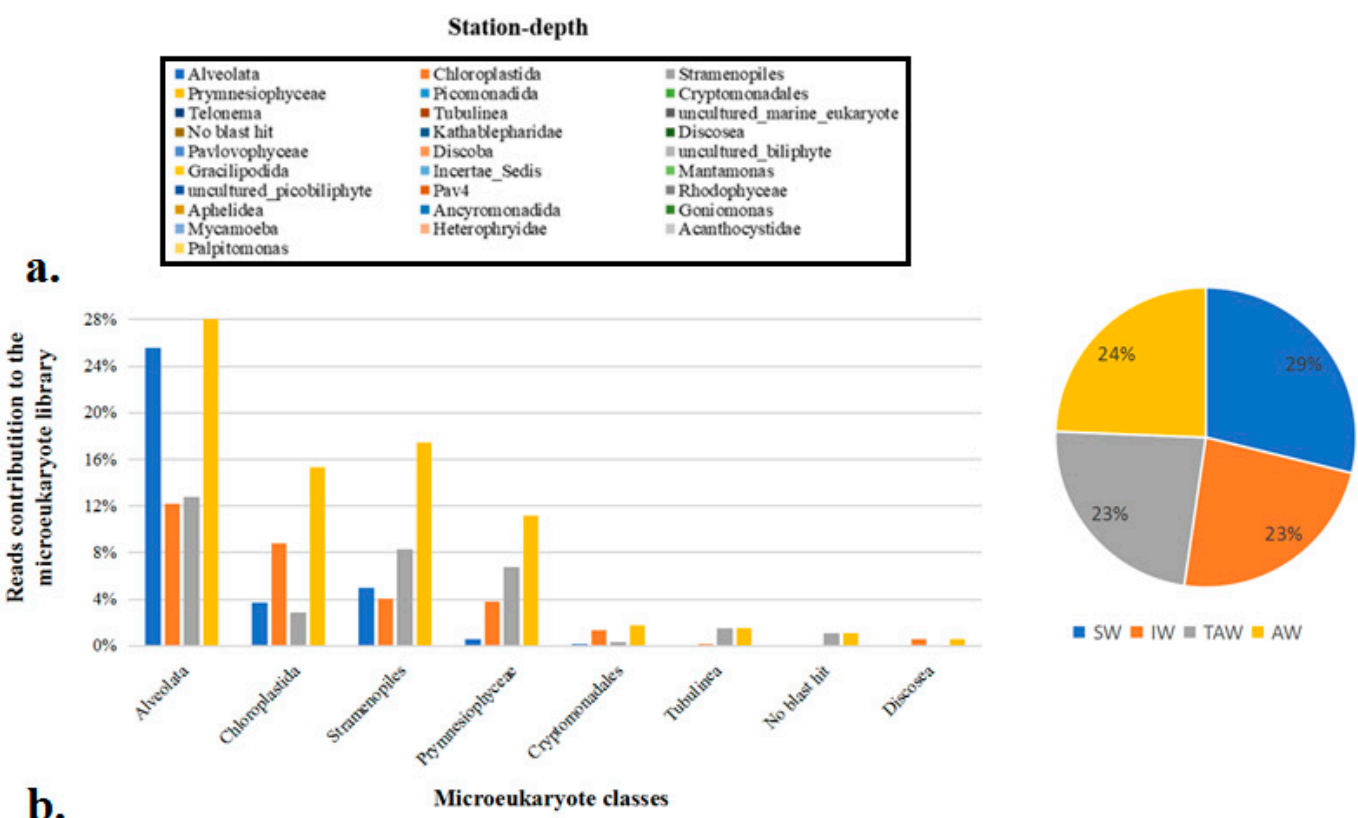

- SW $=\mathrm{IW}=\mathrm{TAW}=\mathrm{AW}$

b.

Figure 9. Proportions of small eukaryotes contributing no less than $1 \%$ to the small eukaryotic DNA liabrary in Kongsfjorden in 2018 at different depths of stations (a) and at different watermasses (b). SW = surface water; IW = intermediate mixed water; TAW $=$ Transformed Atlantic Water.

As said before, $60 \%$ of Svalbard is covered by glaciers and Ny-Ålesund is called a "glacier museum". There are small active microcommunities at the bottom of the glacier surface, where viruses, bacteria, fungi, algae, protozoa and even rotifers and copepods have been detected (Figure 10; $[37,38]$ ). In addition, there are dust holes on the surface 
of glaciers which are formed by dust particles that gather on the surface of glaciers and absorb solar energy. The existence of dust holes results in glacial melting and increases amounts of meltwater in summer. Glacial dust pits are important microhabitats $[39,40]$. For example, 57 species of cyanobacteria and microalgae were found in five glacial dust pits near Kongsfjorden. Dust pits, as special habitats for microorganisms, are important for carbon sequestration and nutrient cycling $[39,40]$. The primary productivity is $0.34-10.56 \mathrm{mg} \mathrm{C} \mathrm{L}^{-1} \mathrm{~h}^{-1}$. Cyanobacteria dominate the dust pit bottom with a high photosynthetic rate of $0.63-156.99 \mathrm{mg} \mathrm{C} \mathrm{L}_{-1} \mathrm{~h}^{-1}$. In addition, there are abundant bacteria on the ice surface, in the ice and on the ice floor, ranging from $10^{4}$ to $10^{7}$ cells $\mathrm{mL}^{-1}[25,41,42]$.

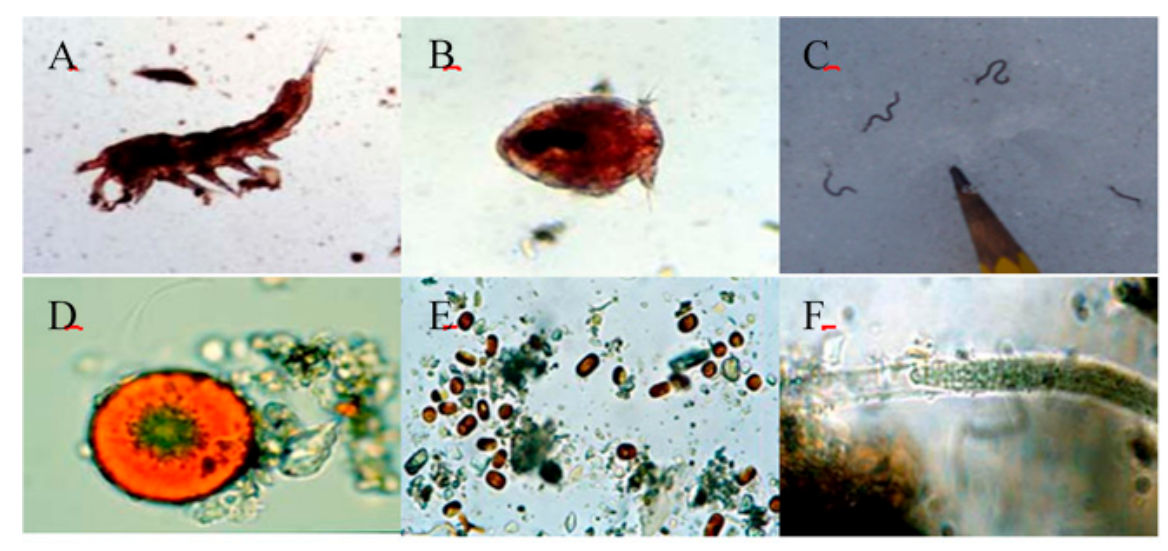

Figure 10. Microbial communites, including (A) copepods, (B) copepods, (C) worms, (D) green algae, (E) green algae and (F) blue bacteria in glacier dust pits.

\section{Effects of Glacial Collapse and Melting on Microbes}

The ancient microbes hidden in ice layers will be released when the glaciers collapse. At the same time, the retreat of glaciers will expose large areas of soil. The original tundra would gradually melt with the rapid Arctic warming. This will release the ancient microbes buried in frozen soil and further change the biological communities there [43,44]. Although the soil contains the most abundant microbes on earth, the diversity and metabolism of these microbes are largely unknown [45]. In the process of glacial meltwater running into coastal waters, the water flows through different tundra carrying different soil microbes. This changes the composition of the microbial community in the coastal waters [25]. For example, cyanobacteria were discovered in Kongsfjorden in 2017. This is a type of ice algae which can be found in glaciers. Different microbes have different environmental correlations [25]. Prokaryotes are more affected by phosphate and nitrogen than by temperature [13]. By contrast, eukaryotes are most affected by temperature. In general, prokaryotes have a higher sensitivity to environmental factors than eukaryotes. Eukaryotes in surface water are affected by temperature, and those in deep water are mainly affected by nutrients. By comparison, Chrysophyceae from fresh water and the $\gamma$-Proteobacteria are almost unaffected by temperature, salinity and macronutrients. Our study shows that the impact of the Atlantic warm current on the microbial community has been exacerbated since 2017. Compared with the mixed water masses, the effects of temperature, salinity and macronutrients in the Atlantic Current are more pronounced in 2019. Environmental change will lead to variations in the interactions among small organisms [31].

All the above studies indicate that the increase of glacial meltwater and input to the Atlantic Warm Current have changed the original plankton community in Kongsfjorden. This has led to great changes in the structure and ecological functions of the entire community. The influences are different in different years (Figure 11) [25]. 

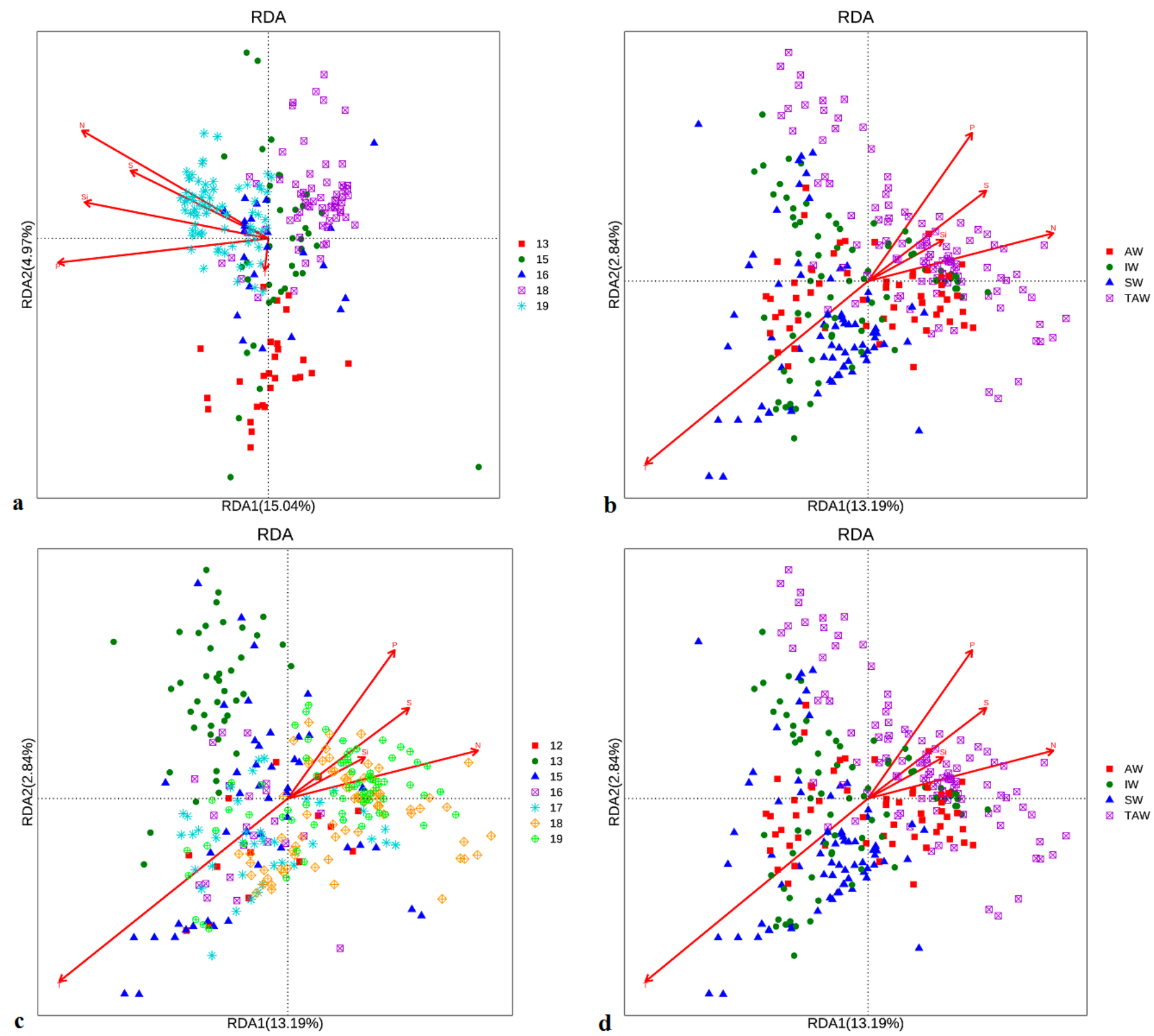

Figure 11. Environmental effects on microbial communities in prokaryotes $(\mathbf{a}, \mathbf{b})$ and eukaryotes $(\mathbf{c}, \mathbf{d})$ in different years $(\mathbf{a}, \mathbf{c})$ and water masses $(\mathbf{b}, \mathbf{d})$.

Environmental factors accounted for $24.11 \%$ of the prokaryotic-environmental correlation in different years in summer (Figure 11a). The first two axes accounted for $20.10 \%$. Among these environmental factors, phosphate is the most influential, followed by total nitrogen (the sum of nitrate, nitrite and ammonia), silicates and salinity. Temperature is the least influential. Community structure in 2019 was obviously affected by the interaction of the five environmental factors. Comparatively, communities in all the other years were slightly affected by temperature or nutrients, with the least influence in 2013. The effects of environmental factors in different water masses are also different (Figure 11b). Temperature is the most influential factor, followed by total nitrogen, phosphate, salinity and silicates. Temperature is the dominant factor influencing the bacterial community in surface water (SW), middle water (IW) and Atlantic warm water mass (TW). Nutrients and salinity gradually become the dominant factors in Atlantic variant water mass (TAW), with slight temperature effects observed in some species [31]. 
Environmental factors accounted for $20.10 \%$ of the prokaryotic-enviromental correlation in different years in summer (Figure 11c). The first two axes accounted for $17.38 \%$. Among these environmental factors, temperature is the most influential, followed by total nitrogen, phosphate, salinity and silicates. The structures of microeukaryotic communities in different years were affected by different interactions of the five environmental factors, except for 2013, where community structure was only slightly affected by temperature, and 2016, where it was mainly affected by temperature. The influence of nutrients and salinity gradually increased from 2015, and the influence of temperature gradually decreased. The environmental effects in different water masses were also different (Figure 11d). The temperature of SW and IW was the dominant factor; nutrients and salinity of TAW gradually became the dominant factors. Different phylotypes in AW were affected by different environmental factors: some were influenced by temperature; some were more influenced by nutrients and salinity. Some were not obviously affected by any environmental factors in Figure 11 [31].

\section{General Studies of $\mathbf{C H}_{4}$-Correlated Microbes in Svalbard}

$\mathrm{CH}_{4}$ is second only to $\mathrm{CO}_{2}$ as a greenhouse gas that accelerates global warming [44-48]. Arctic high-latitude glaciers, tundra, permafrost and seafloor hydrates are large reservoirs of $\mathrm{CH}_{4} \cdot \mathrm{CH}_{4}$ is highly sensitive to temperature [44,49-51]. Once global warming causes glacial collapse and permafrost melting, large amounts of stored $\mathrm{CH}_{4}$ will be released into the atmosphere, causing irreversible effects on the global ecosystem [39,42,52]. $\mathrm{CH}_{4}$ is usually formed by a microbiome-mediated process [40,44,53-55] and is buried in subsea sediments and deep permafrost through long-term fermentation [44]. As well as spreading upward, $\mathrm{CH}_{4}$ is also formed in local anaerobic microenvironments, such as the guts of zooplankton and in particles of copepod feces in surface seawater. These are also important sources of $\mathrm{CH}_{4}$ in seawater and in the atmosphere [56]. In addition, phytoplankton have regulatory effects on $\mathrm{CH}_{4}$. For example, the widely distributed coccolithophores and Phaeocystis can produce $\mathrm{CH}_{4}$ [6]. In contrast, some bacteria can consume $\mathrm{CH}_{4}$ [57]. Therefore, plankton communities have significant influences on the source-sink dynamics of $\mathrm{CH}_{4}$ in seawater. There are complex patterns of "competition" or "cooperative" survival in microbial communities [58].

This complicates community structure, function and interactions. It also complicates the study of the main methanogens-from influencing factors to contributions to microbial interactions [59]. Luckily, bioomics studies, especially macrotranscriptomics, provide effective tools to solve these problems. Metagenomic and metatranscriptome analysis are used to study community structure and functions in glacial cores and their melts, soils, lakes, seawater and sediments [40,44]. However, these studies have hardly been carried out in Svalbard. Biological omics combined with isotopic analysis [54] are useful tools in analyzing the source and sink dynamics of $\mathrm{CH}_{4}$ in Svalbard.

\section{Unanswered Questions about Microbial Correlations with $\mathrm{CH}_{4}$ in Svalbard Needing to Be Addressed}

To sum up, despite the importance of microbes in the production and consumption of methane, we still don't know much about the composition of methanogens and their contribution to methane cycling in different land types in High Arctic Svalbard. Consequently, the following scientific questions that need to be answered are as follows:

(1) How will the microbial community in Svalbard change along with rapid Arctic warming and the environmental change? How does the microbial relationship change alongside?

(2) How does the microbial relationship affect the realization of the ecological functions of microbiomes?

(3) Is Svalbard a source or sink for $\mathrm{CH}_{4}$ in the future? What are the contributions of glacial/permafrost melting, meltwater, soil and microbial mediation to the whole concentration of $\mathrm{CH}_{4}$ in Svalbard? 
(4) What is the influence of microbiome changes in different media in $\mathrm{CH}_{4}$ cycling?

(5) Does $\mathrm{CH}_{4}$ cycling changes in Svalbard greatly influence global $\mathrm{CH}_{4}$ change?

Author Contributions: F.Z. wrote the paper; H.Z. revised the format; S.P. funded and revised the paper; L.Z. provided information on $\mathrm{CH}_{4}$; W.Y. wrote the portions of the manuscript concerning $\mathrm{CH}_{4}$. All authors have read and agreed to the published version of the manuscript.

Funding: This research was funded by National Natural Science Foundation of China (Grant No. 41306175), Key Laboratory of Marine Ecosystem Dynamics, Second Institute of Oceanography, Ministry of Natural Resources, grant number (MED202016), and Open Fund of Key Laboratory of Marine Geology and Environment, Chinese Academy of Sciences (No. MGE2021KG12).

Institutional Review Board Statement: Not applicable.

Informed Consent Statement: Not applicable.

Data Availability Statement: All the data and materials correlated with the paper are included in the text. They are from our own study or the references.

Acknowledgments: Thanks for the useful comments of the four Reviewers.

Conflicts of Interest: The authors declare no conflict of interest.

\section{References}

1. He, J.; Zhang, F.; Lin, L.; Cai, M.; Yang, H.; Wang, X. Effects of the 2010 Chile and 2011 Japan tsunamis on the Antarctic coastal waters as detected via online mooring system. Antarct. Sci. 2012, 24, 665-671. [CrossRef]

2. Zeng, Y.; Zhang, F.; He, J.; Lee, S.H.; Qiao, Z.-Y.; Yu, Y. Bacterioplankton community structure in the Arctic waters as revealed by pyrosequencing of 16S rRNA genes. Antonie Van Leeuwenhoek 2013, 103, 1309-1319. [CrossRef]

3. Zeng, Y.; Luo, W.; Li, H.; Yu, Y. High diversity of planktonic prokaryotes in Arctic Kongsfjorden seawaters in summer 2015. Polar Biol. 2021, 44, 195-208. [CrossRef]

4. Alonso-Sáez, L.; Waller, A.S.; Mende, D.R.; Bakker, K.; Farnelid, H.; Yager, P.L.; Lovejoy, C.; Tremblay, J.É.; Potvin, M.; Heinrich, F.; et al. Role for urea in nitrification by polar marine Archaea. Proc. Natl. Acad. Sci. USA 2012, 109, 17989-17994. [CrossRef] [PubMed]

5. Banerjee, S.; Kennedy, N.; Richardson, A.E.; Egger, K.N.; Siciliano, S.D. Archaeal ammonia oxidizers respond to soil factors at smaller spatial scales than the overall archaeal community does in a high Arctic polar oasis. Can. J. Microbiol. 2016, 62, 485-491. [CrossRef]

6. Lenhart, K.; Klintzsch, T.; Langer, G.; Nehrke, G.; Bunge, M.; Schnell, S.; Keppler, F. Evidence for methane production by the marine algae Emiliania huxleyi. Biogeosciences 2016, 13, 3163-3174. [CrossRef]

7. Klintzsch, T.; Langer, G.; Wieland, A.; Geisinger, H.; Lenhart, K.; Nehrke, G.; Keppler, F. Effects of Temperature and Light on Methane Production of Widespread Marine Phytoplankton. J. Geophys. Res. Biogeosciences 2020, 125, e2020JG005793. [CrossRef]

8. Ye, W.; Wang, X.; Zhang, X.; Zhang, G. Methane production in oxic seawater of the western North Pacific and its marginal seas. Limnol. Oceanogr. 2020, 65, 2352-2365. [CrossRef]

9. van Teeseling, M.C.; Jogler, C. Cultivation of elusive microbes unearthed exciting biology. Nat. Commun. 2021, 12, 75. [CrossRef]

10. Becking, L.G.M.B. Geobiologie of Inleiding Tot De Milieukunde; Van Stockum WP \& Zoon (in Dutch): The Hague, The Netherlands, 1934.

11. Beijerinck, M.W. De Infusies En De Ontdekking Der Backteriën; Jaarboek van de Koninklijke Akademie voor Wetenschappen: Amsterdam, The Netherlands, 1913; Müller. (Reprinted in Verzamelde geschriften van M.W. Beijerinck, vijfde deel. pp. 119-140).

12. Zhang, F.; Cao, S.; Gao, Y.; He, J. Distribution and environmental correlations of picoeukaryotes in an Arctic fjord (Kongsfjorden, Svalbard) during the summer. Polar Res. 2019, 38, 3390-3401. [CrossRef]

13. Cao, S.; Zhang, F.; He, J.; Ji, Z.; Zhou, Q. Water masses influence bacterioplankton community structure in summer Kongs-fjorden. Extremophiles 2020, 24, 107-120. [CrossRef]

14. Bourriquen, M.; Mercier, D.; Baltzer, A.; Fournier, J.; Costa, S.; Roussel, E. Paraglacial coasts responses to glacier retreat and associated shifts in river floodplains over decadal timescales (1966-2016), Kongsfjorden, Svalbard. Land Degrad. Dev. 2018, 29, 4173-4185. [CrossRef]

15. Svendsen, H.; Beszczynska-Møller, A.; Hagen, J.O.; Lefauconnier, B.; Tverberg, V.; Gerland, S.; Børre Ørbæk, J.; Bischof, K.; Papucci, C.; Zajaczkowski, M.; et al. The physical environment of Kongsfjorden-Krossfjorden, an Arctic fjord system in Svalbard. Polar Res. 2002, 21, 133-166.

16. Bradley, J.A.; Anesio, A.M.; Arndt, S. Microbial and biogeochemical dynamics in glacier Forefields are sensitive to century-scale climate and anthropogenic change. Front. Earth Sci. 2019, 5, 26. [CrossRef]

17. Cottier, F.; Tverberg, V.; Inall, M.; Svendsen, H.; Nilsen, F.; Griffiths, C. Water mass modification in an Arctic fjord through cross-shelf exchange: The seasonal hydrography of Kongsfjorden, Svalbard. J. Geophys. Res. Space Phys. 2005, $110,12005$. [CrossRef] 
18. Cottier, F.; Nilsen, F.; Inall, M.E.; Gerland, S.; Tverberg, V.; Svendsen, H. Wintertime warming of an Arctic shelf in response to large-scale atmospheric circulation. Geophys. Res. Lett. 2007, 34, 10607. [CrossRef]

19. Muckenhuber, S.; Korosov, A.A.; Sandven, S. Open-source feature-tracking algorithm for sea ice drift retrieval from Senti-nel-1 SAR imagery. Cryosphere 2016, 10, 913-925. [CrossRef]

20. Wiencke, C.; Hop, H. Ecosystem Kongsfjorden: New views after more than a decade of research. Polar Biol. 2016, 39, 1679-1687. [CrossRef]

21. Lalande, C.; Moriceau, B.; Leynaert, A.; Geisinger, H.; Lenhart, K.; Nehrke, G. Spatial and temporal variability in export fluxes of biogenic matter in Kongsfjorden. Polar Biol. 2017, 39, 1-14. [CrossRef]

22. Bischof, K.; Convey, P.; Duarte, P.; Gattuso, J.-P.; Granberg, M.; Hop, H.; Hoppe, C.; Jiménez, C.; Lisitsyn, L.; Martinez, B.; et al. Kongsfjorden as harbinger of the future arctic: Knowns, unknowns and research priorities. In The Ecosystem of Kongsfjorden, Svalbard; Springer International Publishing: Cham, Switzerland, 2019; pp. 537-562.

23. Hop, H.; Falk-Petersen, S.; Svendsen, H.; Kwasniewski, S.; Pavlov, V.; Pavlova, O.; Søreide, J.E. Physical and biological characteristics of the pelagic system across Fram Strait to Kongsfjorden. Prog. Oceanogr. 2006, 71, 182-231. [CrossRef]

24. Wassmann, P.; Kosobokova, K.N.; Slagstad, D.; Drinkwaterd, K.F.; Hopcrofte, R.R.; Mooref, S.E. The contiguos domains of Arctic Ocean dvection: Trails of life and death. Progr Oceanogr 2015, 139, 42-65. [CrossRef]

25. Zhang, F. Study and Analysis of prokaryotic communities and CH4 changes in the Arctic Kongsfjorden, Svalbar. Open Access J. Biog. Sci. Res. 2021, 8. [CrossRef]

26. Hansen, G.A.; Eilertsen, H.C. Modelling the onset of phytoplankton blooms: A new approach. In Ecology of Fjords and Coastal Waters; Skjoldal, H.R., Hopkins, K.E., Erikstad, K.E., Leinas, H.P., Eds.; Elsevier Science: Amsterdam, The Netherlands, 1995; pp. 73-83.

27. Hegseth, E.N.; Tverberg, V. Effect of Atlantic water inflow on timing of the phytoplankton spring bloom in a high Arctic fjord (Kongsfjorden, Svalbard). J. Mar. Syst. 2013, 113, 94-105. [CrossRef]

28. Keck, A.; Wiktor, J.; Hapter, R.; Nilsen, R. Phytoplankton assemblages related to physical gradients in an Arctic, glacier-fed fjord in summer. ICES J. Mar. Sci. 1999, 56, 203-214. [CrossRef]

29. Piwosz, K.; Walkusz, W.; Hapter, R.; Wieczorek, P.; Hop, H.; Wiktor, J. Comparison of productivity and phytoplankton in a warm (Kongsfjorden) and a cold (Hornsund) Spitsbergen fjord in mid-summer 2002. Polar Biol. 2009, 32, 549-559. [CrossRef]

30. Piwosz, K.; Spich, K.; Całkiewicz, J.; Weydmann, A.; Kubiszyn, A.M.; Wiktor, J.M. Distribution of small phytoflagellates along an Arctic fjord transect. Environ. Microbiol. 2015, 17, 2393-2406. [CrossRef]

31. Zhang, F.; He, J.; Jin, H.; Hao, Q.; Gao, Z.; Sun, H. Comparison of picoeukaryote community structures and their environmental relationships between summer and autumn in the southern Chukchi Sea. Extremophiles 2021, 25, 235-248. [CrossRef]

32. Dalpadado, P.; Hop, H.; Rønning, J.; Gerland, S.; Tverberg, V.; Svendsen, H. Distribution and abundance of euphausiids and pelagic amphipods in Kongsfjorden, Isfjorden and Rijpfjorden (Svalbard) and changes in their relative importance as key prey in a warming marine ecosystem. Polar Biol. 2016, 39, 1765-1784. [CrossRef]

33. Fang, Z.; Yongjun, T.; Jianfeng, H. Prevalence of a type of freshwater mixotrophic chrysophyte in a high Arctic maine ecosystem in a summer situation. Water 2021, 15, 2129, Accepted.

34. Caroppo, C.; Pagliara, P.; Azzaro, F.; Miserocchi, S.; Azzaro, M. Late summer phytoplankton blooms in the changing polar environment of the kongsfjorden (Svalbard, Arctic). Cryptogam. Algologie 2017, 38, 53-72. [CrossRef]

35. Feng, M.; Zhang, W.; Xiao, T. Spatial and temporal distribution of tintinnid (Ciliophora: Tintinnida) communities in Kongsfjorden, Svalbard (Arctic), during summer. Polar Biol. 2014, 37, 291-296. [CrossRef]

36. Gluchowska, M.; Kwasniewski, S.; Prominska, A.; Olszewska, A.; Goszczko, I.; Falk-Petersen, S.; Hop, H.; Weslawski, J.M. Zooplankton in Svalbard fjords on the Atlantic-Arctic boundary. Polar Biol. 2016, 39, 1785-1802. [CrossRef]

37. Wharton Jr, R.A.; Vinyard, W.C.; Parker, B.C.; Drinkwaterd, K.F.; Hopcrofte, R.R.; Mooref, S.E. Berge Algae in cryoconite holes on the Canada Glacierin southern Victoria Land. Antarct. Phycol. 1981, 20, 208-211. [CrossRef]

38. Christner, B.C.; Kvitko, B.H.; Reeve, J.N. Molecular molecular identification of bacteria and eukarya inhabiting an Antarctic cryoconitehole. Extremophiles 2003, 7, 177-183. [CrossRef]

39. Zumsteg, A.; Luster, J.; Göransson, H.; Smittenberg, R.H.; Brunner, I.; Bernasconi, S.M.; Zeyer, J.; Frey, B. Bacterial, Archaeal and Fungal Succession in the Forefield of a Receding Glacier. Microb. Ecol. 2012, 63, 552-564. [CrossRef] [PubMed]

40. Anesio, A.M.; Lutz, S.; Chrismas, N.A.M.; Benning, L.G. The microbiome of glaciers and ice sheets. Npj Biofilms Microbiomes 2017, 3, 10-21. [CrossRef] [PubMed]

41. Monger, B.C.; Landry, M.R. Flow cytometric analysis of marine bacteria with hoechst 33342. Appl. Environ. Microbiol. 1993, 59, 905-911. [CrossRef] [PubMed]

42. Mueller, D.R.; Pollard, W.H. Gradient analysis of cryoconite ecosystems from two polar glaciers. Polar Biol. 2004, $27,66-74$. [CrossRef]

43. Shur, Y.L.; Jorgenson, M.T. Patterns of permafrost formation and degradation in relation to climate and ecosystems. Permafr. Periglac. Process. 2007, 18, 7-19. [CrossRef]

44. Altshuler, I.; Hamel, J.; Turney, S.; Magnuson, E.; Lévesque, R.; Greer, C.W.; Whyte, L.G. Species interactions and distinct microbial communities in high Arctic permafrost affected cryosols are associated with the $\mathrm{CH}_{4}$ and $\mathrm{CO}_{2}$ gas fluxes. Environ. Microbiol. 2019, 21, 3711-3727. [CrossRef] 
45. Schloter, M.; Nannipieri, P.; Sørensen, S.; Van Elsas, J.D. Microbial indicators for soil quality. Biol. Fertil. Soils 2018, 54, 1-10. [CrossRef]

46. Vary, P.; Johnson, M. Cell yields of bacteria grown on methane. Appl. Microbiol. 1967, 15, 1473-1478. [CrossRef] [PubMed]

47. Schuur, E.A.G.; McGuire, A.D.; Schadel, C.; Grosse, G.; Harden, J.W.; Hayes, D.J.; Hugelius, G.; Koven, C.D.; Kuhry, P.; Lawrence, D.M.; et al. Climate change and the permafrost carbon feedback. Nature 2015, 520, 171-179. [CrossRef]

48. Mauritz, M.; Bracho, R.; Celis, G.; Hutchings, J.; Natali, S.M.; Pegoraro, E.; Salmon, V.G.; Schädel, C.; Webb, E.E.; Schuur, E.A.G. Nonlinear $\mathrm{CO}_{2}$ flux response to 7 years of experimentally induced permafrost thaw. Glob. Chang. Biol. 2017, 23, 3646-3666. [CrossRef]

49. Verville, J.; Hobbie, S.; Iii, F.S.C.; Hooper, D. Response of tundra $\mathrm{CH}_{4}$ and $\mathrm{CO}_{2}$ flux tomanipulation of temperature and vegetation. Biogeochemistry 1998, 41, 215-235. [CrossRef]

50. Tarnocai, C.; Canadell, J.G.; Schuur, E.A.; Kuhry, P.; Mazhitova, G.; Zimov, S. Soil organic carbon pools in the northern cir-cumpolar permafrost region. Glob. Biogeochem. Cycles 2009, 23, GB2023. [CrossRef]

51. Marushchak, M.E.; Pitkämäki, A.; Koponen, H. Hot spots for nitrous oxide emissions found in different types of permafrost peatlands. Glob. Chang. Biol. 2011, 17, 2601-2614. [CrossRef]

52. Stackhouse, B.T.; Vishnivetskaya, T.A.; Layton, A.; Chauhan, A.; Pfiffner, S.; Mykytczuk, N.C.; Sanders, R.; Whyte, L.G.; Hedin, L.; Saad, N.; et al. Effects of simulated spring thaw of permafrost from mineral cryosol on $\mathrm{CO}_{2}$ emissions and atmospheric $\mathrm{CH}_{4}$ uptake. J. Geophys. Res. Biogeosci. 2015, 120, 1764-1784. [CrossRef]

53. Mackelprang, R.; Saleska, S.R.; Jacobsen, C.S.; Nehrke, G.; Bunge, M.; Schnell, S. Permafrost Meta-Omics and Climate Change. Annu. Rev. Earth Planet. Sci. 2016, 43, 439-462. [CrossRef]

54. Christiansen, C.; Haugwitz, M.S.; Priemé, A.; Nielsen, C.S.; Elberling, B.; Michelsen, A.; Grogan, P.; Blok, D. Enhanced summer warming reduces fungal decomposer diversity and litter mass loss more strongly in dry than in wet tundra. Glob. Chang. Biol. 2016, 23, 406-420. [CrossRef]

55. Bush, T.; Diao, M.; Allen, R.J.; Benning, L.G. Oxic-anoxic regime shifts mediated by feedbacks between biogeochemical pro-cesses an and microbial community dynamics. Nat. Commun. 2017, 8, 789-798. [CrossRef] [PubMed]

56. Karl, D.; Tilbrook, B. Production and transport of methane in oceanic particulate organic matter. Nat. Cell Biol. 1994, 368, 732-734. [CrossRef]

57. Conrad, R. Soil microorganisms as controllers of atmospheric trace gases (H2, CO, CH4, OCS, N2O, and NO). Microbiol. Rev. 1996, 60, 609-640. [CrossRef] [PubMed]

58. Hoare, A.; Wang, H.; Meethil, A.; Abusleme, L.; Hong, B.-Y.; Moutsopoulos, N.M.; Marsh, P.D.; Hajishengallis, G.; Diaz, P.I. A cross-species interaction with a symbiotic commensal enables cell-density-dependent growth and in vivo virulence of an oral pathogen. ISME J. 2021, 15, 1490-1504. [CrossRef]

59. Kieft, B.; Li, Z.; Bryson, S.; Crump, B.C.; Hettich, R.; Pan, C.; Mayali, X.; Mueller, R.S. Microbial community structure-function relationships in yaquina bay estuary reveal spatially distinct carbon and nitrogen cycling capacities. Front. Microbiol. 2018, 9 , 1282. [CrossRef] [PubMed] 